\title{
WATERMELON INITIAL GROWTH UNDER DIFFERENT HYDROGEL CONCENTRATIONS AND SHADING CONDITIONS ${ }^{1}$
}

\author{
BRENO DE JESUS PEREIRA ${ }^{2 *}$, GUSTAVO ARAÚJO RODRIGUES ${ }^{3}$, ANACLETO RANULFO DOS \\ SANTOS $^{4}$, GILVANDA LEÃO DOS ANJOS ${ }^{4}$, FRANCIELE MEDEIROS COSTA ${ }^{4}$
}

\begin{abstract}
Watermelon (Citrullus lanatus) belongs to the plant family Cucurbitaceae. It is cultivated in many regions of Brazil, particularly in rainfed areas; thus, it is subject to the problems arising from irregular rainfall. Hydrogel is a soil conditioner used to retain and provide water to plants for long periods of time. Therefore, incorporating hydrogel into the soil should increase water availability for watermelon cultivation, and may be an alternative method to reduce the risk of water deficit. This study evaluated the effect of different concentrations of hydrogel on the initial growth of watermelon cv. 'Crimson Sweet' under different shading conditions. The experiment was carried out in a greenhouse with completely randomized design with a $4 \times 3$ factorial scheme. The treatments consisted of four hydrogel doses $\left(0.0 ; 1.5 ; 3.0\right.$; and $6.0 \mathrm{~g} \mathrm{~L}^{-1}$ substrate), three shading conditions (under full sun; black shade net, and red shade net, both with $50 \%$ shading), and five replicates per treatment. The variables evaluated were plant height; stem diameter; shoot, root, and total dry matter; and leaf area. The best hydrogel dose for watermelon cultivation was $1.5 \mathrm{~g} \mathrm{~L}^{-1}$, but the higher doses impaired plant growth, regardless of shading conditions. The black net improved biomass accumulation in 'Crimson Sweet' watermelon, whereas the red net induced plant etiolation.
\end{abstract}

keywords: Citrullus lanatus. Soil conditioner. Shade nets.

\section{CRESCIMENTO INICIAL DE MELANCIEIRA EM DIFERENTES CONCENTRAÇÕES DE HIDROGEL E CONDIÇÕES DE SOMBREAMENTO}

\begin{abstract}
RESUMO - A melancieira é uma cucurbitácea cultivada em várias regiões do Brasil, principalmente, em áreas de sequeiro, sujeito aos riscos da irregularidade das chuvas. O hidrogel é um condicionador do solo utilizado para reter e disponibilizar água para as plantas por períodos prolongados. Assim, a incorporação do hidrogel no solo visando aumentar a disponibilidade de água para o cultivo da melancieira pode ser uma alternativa para diminuir os riscos de déficit hídrico. Diante do exposto, objetivou avaliar o efeito do hidrogel no crescimento inicial de melancieira cultivar 'Crimson Sweet', em diferentes condições de sombreamento. O trabalho foi realizado em casa de vegetação, organizado experimentalmente no delineamento inteiramente casualizado, em esquema fatorial $4 \times 3$, sendo o primeiro fator quatro doses de hidrogel $\left(0,0 ; 1,5 ; 3,0 ; 6,0 \mathrm{~g} \mathrm{~L}^{-1}\right.$ de substrato) e o segundo fator três ambientes de sombreamento (sol pleno; malha de cor preta e malha fotoconversora de cor vermelha, ambas com $50 \%$ de sombreamento), e cinco repetições por tratamento. Procedeu-se as análises das seguintes variáveis: altura das plantas, diâmetro do caule, massa seca da parte aérea, massa seca da raiz, massa seca total e área foliar. A melhor concentração dentre aquelas testadas para o cultivo de melancieira foi de $1,5 \mathrm{~g}$ $\mathrm{L}^{-1}$ de hidrogel, sendo que doses superiores não favorecem o crescimento das plantas, independentemente das condições de sombreamento. $\mathrm{O}$ uso da malha preta favoreceu o acúmulo de massa em plantas de melancia 'Crimson Sweet' enquanto a malha vermelha induziu ao estiolamento das plantas.
\end{abstract}

Palavras-chave: Citrullus lanatus. Condicionador de solo. Malhas de sombreamento.

\footnotetext{
${ }^{*}$ Corresponding author

${ }^{1}$ Received for publication in $02 / 21 / 2019$; accepted in $10 / 09 / 2019$.

Paper extracted from research of the conclusion work of agronomy course of the first author.

${ }^{2}$ Department of Plant Production (Horticulture), Universidade Estadual Paulista "Júlio de Mesquita Filho", Jaboticabal, SP, Brazil; brenojp93@gmail.com - ORCID: 0000-0002-3419-6609.

${ }^{3}$ Engineering Unit, Agência de Fomento do Estado da Bahia, Salvador, BA, Brazil; r.gustavoaraujo@gmail.com - ORCID: 0000-00028396-5646.

${ }^{4}$ Center for Agricultural, Environmental and Biological Sciences, Universidade Federal do Recôncavo da Bahia, Cruz das Almas, BA, Brazil; anacletosantos86@gmail.com - ORCID: 0000-0003-4629-3948, gilvandas218s2@hotmail.com - ORCID: 0000-0003-4624-1339, fran-eng@hotmail.com - ORCID: 0000-0002-3800-5646.
} 


\section{INTRODUCTION}

Watermelon (Citrullus lanatus) is a cucurbit cultivated in various regions of Brazil and accounts for around 105,491 ha of cultivated land. The largest producing states in the country are Rio Grande do Sul (346,310 tons), São Paulo (291,846 tons), Goiás (267,896 tons), Bahia (239,177 tons), and Tocantins (232,907 tons) (IBGE, 2018). The cultivation of this vegetable is of great economic and social importance because it is mainly carried out by family farmers.

Some of the challenges faced by growers are producing quality fruits while maintaining high production levels throughout the year, which is difficult because watermelon is mainly grown in dryland areas (OLIVEIRA et al., 2015b). This means that it is subject to irregular rainfall, which influences its yield. It has been suggested that hydrogel incorporation into the soil may be an alternative method that could be used to reduce the risk of water deficit or, in cases where irrigation is needed, to reduce the volume of water used. The more efficient use of water should lead to improvements in crop yields (MONTESANO et al., 2015; LOPES et al., 2017).

Hydrogel is a synthetic or natural soil conditioner that retains and provides water to plants for extended periods (AHMED, 2015). When incorporated into the soil, it significantly improves soil physical properties by increasing soil moisture and decreasing water evaporation rates (CÂMARA et al., 2011; YANG et al., 2014). Previous studies have shown that hydrogel improves the growth of yellow passion fruit (FAGUNDES et al., 2015), lettuce (SANTOS et al., 2015), jatropha (DRANSKI et al., 2013), and eucalyptus (BERNARDI et al., 2012) seedlings. However, no studies have analyzed hydrogel effects on watermelon.

Cultivation in protected environments is a technology that improves the physical protection and acclimatization of plants. It generates micrometeorological changes that alter environmentplant relationships (REGO; POSSAMAI, 2006; SHAHAK, 2008). The use of colored shade nets at sites subject to high temperatures and light intensity reduces the amount of radiant energy, which positively affects physiological processes in most plants (ARAÚJO et al., 2006; HENRIQUE et al., 2011). However, there have been few studies about how shading affects watermelon plants. Furthermore, there seems to be no reports about the association between hydrogel and shade nets when they are both used to cultivate plant species.

Therefore, this study evaluated the effect of different concentrations of hydrogel on the initial growth of watermelon under different shading conditions.

\section{MATERIALS AND METHODS}

The experiment was carried out between November, 2017 and January, 2018 in a greenhouse at the Soil and Plant Mineral Nutrition sector of the Federal University of Recôncavo da Bahia - UFRB (12³9'32" S; 39॰5'9” W) in Cruz das Almas City, Bahia State, Brazil.

The experiment had a completely randomized design with a $4 \times 3$ factorial scheme. The first factor was the four hydrogel doses $\left(0.0 ; 1.5 ; 3.0 ; 6.0 \mathrm{~g} \mathrm{~L}^{-1}\right.$ substrate) and the second factor was the three shading environments (full sun; black net; and red net, both with $50 \%$ shading). There were five replicates per treatment.

Watermelon cultivar 'Crimson Sweet' seeds were sown in 200-cell plastic trays containing washed sand. The trays were arranged on benches in an arched-roof greenhouse covered with transparent, low-density polyethylene film. It also had anti-aphid screens along the sides. At 14 days after sowing, when the first permanent leaf pair had formed, the seedlings were transplanted to $2.6 \mathrm{dm}^{3}$ pots at a sowing rate of one plant per pot.

The substrate used consisted of $90 \%$ washed sand and $10 \%$ expanded vermiculite. The plant nutritional needs were met by applying Hoagland and Arnon (1950) solution, diluted to 50\% after the first week of application. Hydrogel at different doses was added and homogenized into the dry substrate. The commercial product acrylamide potassium acrylate copolymer (class E, Plant Gel) from FORTH $^{\circledR}$ was used. According to the manufacturer, the amount of water absorbed is 200 to 400 times its initial weight and its size increases by up to 100 times.

Pot capacity (equivalent to field capacity) was determined at the UFRB Soil Physics Laboratory. In the laboratory, three replicates of the pots with the same volume used in the experiment were filled with the substrate. A cylindrical PVC tube, which was 20 $\mathrm{cm}$ in height and $2.54 \mathrm{~cm}$ in diameter, was inserted into the center of the pot and filled with the substrate (washed sand $+10 \%$ vermiculite). The substrate was lightly tapped with a spatula to reduce the voids. Then, about $100 \mathrm{~mL}$ of water (corresponding to the volume of the tube) was added and the tops of both the tube and the pot were covered with film paper to prevent evaporative water loss. Excess water was drained into the dry substrate, and the water retained in the substrate within the tube was used to determine the field capacity. After 24 hours, a substrate fraction was taken from the middle part of the tube, placed in a capsule, and weighed to obtain the wet substrate weight (WSW). Subsequently, the capsule containing the substrate was placed in an oven at $105^{\circ} \mathrm{C}$ for 24 hours and then weighed to obtain the dry substrate weight (DSW). Gravimetric moisture $(\mu \mathrm{g} \%)$ was obtained using the formula: 
$\mu_{\mathrm{g}} \%=\mathrm{WSW}-\mathrm{DSW} / \mathrm{DSW} \times 100$

The $\mu_{g}$ value was $3.0 \%$.

Then, the gravimetric moisture value was converted to volumetric moisture $(\theta)$ by multiplying the $\mu_{g}$ value by the substrate density $(\mathrm{sd}=1.8)$ using the following formula:

$$
\theta=\mu_{\mathrm{g}}(\%) \times \mathrm{sd}
$$

The $\theta$ value was $5.4 \%$.

After the conversions, the substrate water storage at pot capacity $\left(\theta_{c c}\right)$ and the total water availability (TWA) in the substrate were determined to be approximately $100 \mathrm{~mL}$.

Then, the actual water availability (AWA) in the substrate was calculated using the depletion factor (f) tabulated for the watermelon crop by the following formula:

$$
\mathrm{AWA}=\mathrm{TWA} \times \mathrm{f}
$$

The TWA value was 0.54 and the $\mathrm{f}$ value, based on the reference evapotranspiration (ETo) for Cruz das Almas city, Bahia State, was 0.45.

After obtaining the value for the actual water availability in the substrate $\left(\mathrm{AWA}=0.243 \mathrm{~mm} \mathrm{~cm}^{-1}\right.$ substrate), the critical moisture point for new irrigation was determined using the following formula:

$$
\mathrm{AWA}=\left(\theta_{\text {cc }}-\theta_{\text {critical }}\right) \times 10
$$

where: $\mathrm{AWA}=$ actual water availability in the substrate; $\theta_{c c}=$ moisture at pot capacity; and $\theta_{\text {critical }}$ $=$ the critical moisture point for irrigation.

The $\theta_{\text {critical }}$ value was $2.97 \%$, i.e., after the appropriate conversions, irrigation was performed whenever the water content in the pots reached 59 $\mathrm{mL}$.

During the experiment implementation period, the weight of the pots filled with the dry substrate was recorded along with the weight at pot capacity, that is, after adding $100 \mathrm{~mL}$ of water. The plants were manually watered, and the water content needed to supply the water demand after the crop reached the critical point was controlled by weighing the pots every day using an analytical balance.

At 30 days after transplanting the seedlings into the pots, the following variables were analyzed: plant height $(\mathrm{cm})$, stem diameter $(\mathrm{mm})$, root length $(\mathrm{cm})$, shoot dry weight $(\mathrm{g})$, root dry weight $(\mathrm{g})$, total dry weight $(\mathrm{g})$, and leaf area $\left(\mathrm{cm}^{2}\right)$.

A millimeter ruler was used to determine plant height (by measuring the distance from the neck to the apex of the plants) and root length. The stem diameter was measured with a $0.01 \mathrm{~mm}$ digital caliper, and the shoot and root dry weights were determined after drying the material in an oven at $65^{\circ} \mathrm{C}$ and then weighing the shoots and roots on an electronic analytical balance to an accuracy of 0.001 g. Total dry weight was obtained by summing the shoot and root dry weights.

The leaf disc method was used to measure the leaf area after collecting the apical, median, and basal leaves. Then, 10 discs with an area of $0.7 \mathrm{~cm}^{2}$ were taken from each leaf. After drying and weighing the discs, leaf area was estimated using the following formula:

$$
\mathrm{LA}=[(\mathrm{LW}+\mathrm{DW}) \times \mathrm{DA}] / \mathrm{DW}
$$

where: $\mathrm{LA}=$ estimated leaf area $\left(\mathrm{cm}^{2}\right) ; \mathrm{LW}=$ leaf dry weight $(\mathrm{g})$; DW = disc dry weight $(\mathrm{g})$; and DA = known area of the disc leaf $\left(0.7 \mathrm{~cm}^{2}\right)$.

The data were subjected to analysis of variance via the $F$ test using the $R$ statistical program (R TEAM, 2015). The means of the variables that were significantly affected by the shading treatments were compared using Tukey's test at the 5\% probability level. The effects of the different hydrogel doses were analyzed by polynomial regression. A model that used the higher $\mathrm{R}^{2}$ values was adopted and the results were graphed using SigmaPlot software.

\section{RESULTS AND DISCUSSION}

There was significant interaction between the two factors studied and plant height, stem diameter, shoot dry weight, and leaf area variables. However, there was isolated effect of shading condition and hydrogel dose on plant height; stem diameter; root length; shoot, root, and total dry weight; and leaf area of 'Crimson Sweet' watermelon plants.

Analyzing the interactive effect of shading conditions at each hydrogel dose on the variables showed that the plants grown under red net shading were significantly taller than those grown under black net shading and full sun (Table 1) at hydrogel doses of $0 \mathrm{~g} \mathrm{~L}^{-1}$ (control dose) and $1.5 \mathrm{~g} \mathrm{~L}^{-1}$. However, there was no difference between shading conditions for the other doses.

Red net shading stimulated plant height, which may have caused the different levels of etiolation in watermelon plants at the lowest hydrogel doses. This stimulation occurred because the red nets modified the transmitted radiation spectrum, which increased the absorption of light in the red and far-red spectra (SHAHAK, 2008). The stem diameter of plants under full sun was larger than the stem diameters of the plants grown under black and red net shading (Table 1) at $1.5 \mathrm{~g} \mathrm{~L}^{-1}$ hydrogel and black net shading at $3.0 \mathrm{~g} \mathrm{~L}^{-1}$. There were no significant differences between shading conditions for the other doses. These results agreed with Oliveira et al. (2015a) who reported that 
'Crimson Sweet' watermelon seedlings tend to etiolate when shaded, but this was dependent on the type of material used.

Plants grown under full sun had higher shoot dry weights than those shaded with black and red nets (Table 1) at $3.0 \mathrm{~g} \mathrm{~L}^{-1}$ hydrogel. This variable was not significantly different between the red and black shading environments for the other hydrogel concentrations.

Leaf area was greater when the plants were exposed to red net shading (Table 1) at $0.0 \mathrm{~g} \mathrm{~L}^{-1}$ hydrogel. Oliveira et al. (2017) suggested that increasing the photosynthetic surface area may be a strategy used by plants to increase the radiation collection area. There were no significant differences between shading conditions at 1.5 and $6.0 \mathrm{~g} \mathrm{~L}^{-1}$ hydrogel. However, at $3.0 \mathrm{~g} \mathrm{~L}^{-1}$, the plants grown under full sun and under black net shading were significantly taller than those grown under red net shading (Table 1), which indicated that this hydrogel concentration led to an increase in leaf area. This may be related to the higher shoot dry matter accumulation under these conditions.

Table 1. Shading condition and hydrogel dose interaction values for plant height, stem diameter, shoot dry weight (SDW), and the leaf area (LA) of watermelon cv. 'Crimson Sweet' ${ }^{(1)}$.

\begin{tabular}{|c|c|c|c|c|c|c|}
\hline \multirow{2}{*}{ Hydrogel doses $\left(\mathrm{g} \mathrm{L}^{-1}\right)$} & \multicolumn{3}{|c|}{ Plant height (cm) } & \multicolumn{3}{|c|}{ Stem diameter $(\mathbf{m m})$} \\
\hline & $\mathbf{R N} \mathbf{N}^{(2)}$ & BN & FS & $\mathbf{R N}$ & BN & FS \\
\hline 0.0 & $32.2 \mathrm{a}$ & $18.0 \mathrm{~b}$ & $9.7 \mathrm{c}$ & $3.37 \mathrm{a}$ & $3.98 \mathrm{a}$ & $3.42 \mathrm{a}$ \\
\hline 1.5 & $26.7 \mathrm{a}$ & $20.6 \mathrm{~b}$ & $12.5 \mathrm{c}$ & $3.73 \mathrm{~b}$ & $3.52 \mathrm{~b}$ & $5.17 \mathrm{a}$ \\
\hline 3.0 & $10.1 \mathrm{a}$ & $8.4 \mathrm{a}$ & $7.5 \mathrm{a}$ & $2.92 \mathrm{ab}$ & $2.47 \mathrm{~b}$ & $3.63 \mathrm{a}$ \\
\hline 6.0 & $7.1 \mathrm{a}$ & $7.7 \mathrm{a}$ & $5.7 \mathrm{a}$ & $2.67 \mathrm{a}$ & $2.57 \mathrm{a}$ & $2.85 \mathrm{a}$ \\
\hline \multirow{2}{*}{ Hydrogel doses $\left(\mathrm{g} \mathrm{L}^{-1}\right)$} & \multicolumn{3}{|c|}{ SDW (g) } & \multicolumn{3}{|c|}{$\mathbf{L A}\left(\mathrm{cm}^{2}\right)$} \\
\hline & $\mathbf{R N}$ & BN & FS & $\mathbf{R N}$ & BN & FS \\
\hline 0.0 & $0.47 \mathrm{a}$ & $0.48 \mathrm{a}$ & $0.38 \mathrm{a}$ & $90.05 \mathrm{a}$ & $73.39 \mathrm{a}$ & $52.26 \mathrm{~b}$ \\
\hline 1.5 & $0.46 \mathrm{a}$ & $0.58 \mathrm{a}$ & $0.52 \mathrm{a}$ & 76.49 a & $87.30 \mathrm{a}$ & $76.59 \mathrm{a}$ \\
\hline 3.0 & $0.13 \mathrm{~b}$ & $0.19 \mathrm{~b}$ & $0.35 \mathrm{a}$ & $29.75 \mathrm{~b}$ & $34.41 \mathrm{a}$ & $39.12 \mathrm{a}$ \\
\hline 6.0 & $0.09 \mathrm{a}$ & $0.19 \mathrm{a}$ & $0.12 \mathrm{a}$ & $15.20 \mathrm{a}$ & $31.90 \mathrm{a}$ & $24.40 \mathrm{a}$ \\
\hline
\end{tabular}

\footnotetext{
${ }^{(1)}$ Means followed by the same letters in the rows do not differ from each other according to the Tukey test results at the $5 \%$ probability level.

${ }^{(2)} \mathrm{RN}=$ red net; $\mathrm{BN}=$ black net; FS = full sun.
}

The results for the interaction between doses and environments showed that increasing the polymer concentration reduced the plant height increase under black net shading and full sun (Figure 1 ), and this interaction was best described by a negative linear line relationship. However, red net shading had a negative relationship that was best described by an inverse quadratic regression curve.
The best responses for this variable occurred when $1.5 \mathrm{~g} \mathrm{~L} \mathrm{~L}^{-1}$ hydrogel was applied, which led to increases of $14.4 \%$ and $28.8 \%$ compared to the control dose $\left(0.0 \mathrm{~g} \mathrm{~L}^{-1}\right)$ under the black net shading and full sun conditions, respectively. In the absence of hydrogel or at low concentrations of hydrogel, the plants were taller when they were grown under the nets, especially those grown under red nets. 


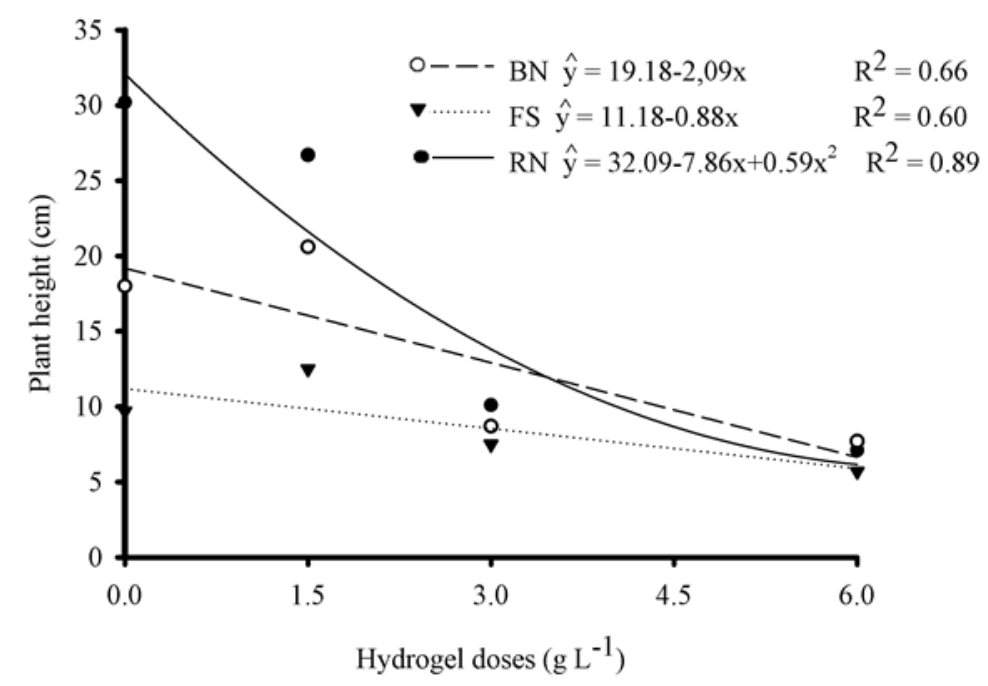

Figure 1. 'Crimson Sweet' watermelon plant heights as a function of hydrogel dose and shading condition (black net - BN; full sun-FS; and red net - RN).

Significant polymer dose responses were observed for stem diameter (Figure 2), with a negative linear fit for shading with black and red nets and a quadratic fit for the full sun treatment. Under full sun, the maximum stem diameter calculated from the quadratic equation was $4.40 \mathrm{~mm}$ at $1.36 \mathrm{~g} \mathrm{~L}$ ${ }^{-1}$ hydrogel (Figure 2). This result indicated that hydrogel had a detrimental effect at doses above 1.36 $\mathrm{g} \mathrm{L}^{-1}$ under the full sun conditions. When shaded with a red net, the watermelon plant diameter increased by $11.0 \%$ at $1.5 \mathrm{~g} \mathrm{~L}^{-1}$ compared to the control. In the absence of the polymer, the greatest increase in plant diameter occurred under the black net.

Fagundes et al. (2015) found that hydrogel favored the growth of yellow passion fruit seedlings up to a dose of $1.49 \mathrm{~g} \mathrm{~L}^{-1}$. According to Bernardi et al. (2012), this growth improvement in the presence of the polymer is associated with substrate nutrient retention capacity because, in the presence of the polymer, the substrate nutrients were made available to the plants in a more gradual and efficient manner.

In contrast, the reduction in plant height and diameter when using hydrogel concentrations above $1.36 \mathrm{~g} \mathrm{~L}^{-1}$ under full sun and above $1.5 \mathrm{~g} \mathrm{~L}^{-1}$ under the two shading conditions suggested that excessive amounts of hydrogel influenced the physical properties of the substrate. The expansive capacity of hydrogel may have altered the porosity of the substrate and, consequently, decreased the aeration and movement of solutes, which would hinder the absorption of water and nutrients by plants, as found by Vichiato et al. (2004), Moreira et al. (2010), Dranski et al. (2013), and Gilbert et al. (2014).

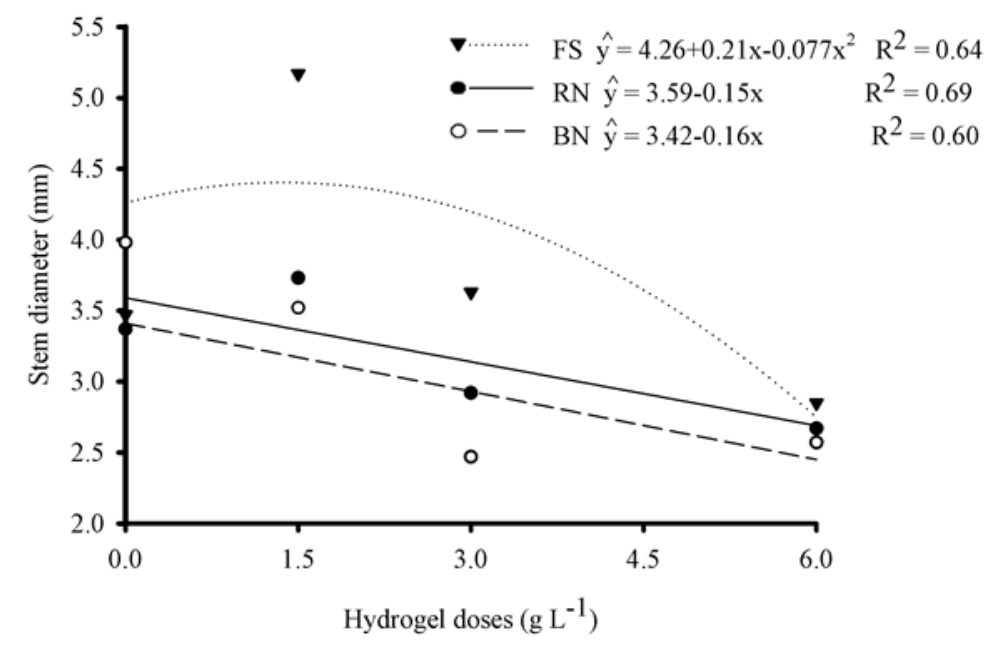

Figure 2. 'Crimson Sweet' watermelon stem diameters as a function of hydrogel dose and shading condition (black net $\mathrm{BN}$; full sun - FS; and red net - RN). 
The quadratic equation for the effect of hydrogel dose on shoot dry weight under full sun indicated that hydrogel contributed to the increase in this parameter up to a dose of $1.55 \mathrm{~g} \mathrm{~L}^{-1}$, with the maximum value being $0.44 \mathrm{~g}$ dry weight (Figure 3 ). Under the two shading conditions, higher hydrogel doses caused a linear decrease in shoot dry matter accumulation (Figure 3), which was due to reduced nutrient absorption and assimilation. However, plant shoot dry weights improved when $1.5 \mathrm{~g} \mathrm{~L}^{-1}$ hydrogel was applied, with an increase of $21.0 \%$ compared to the control for the black net shading treatment.

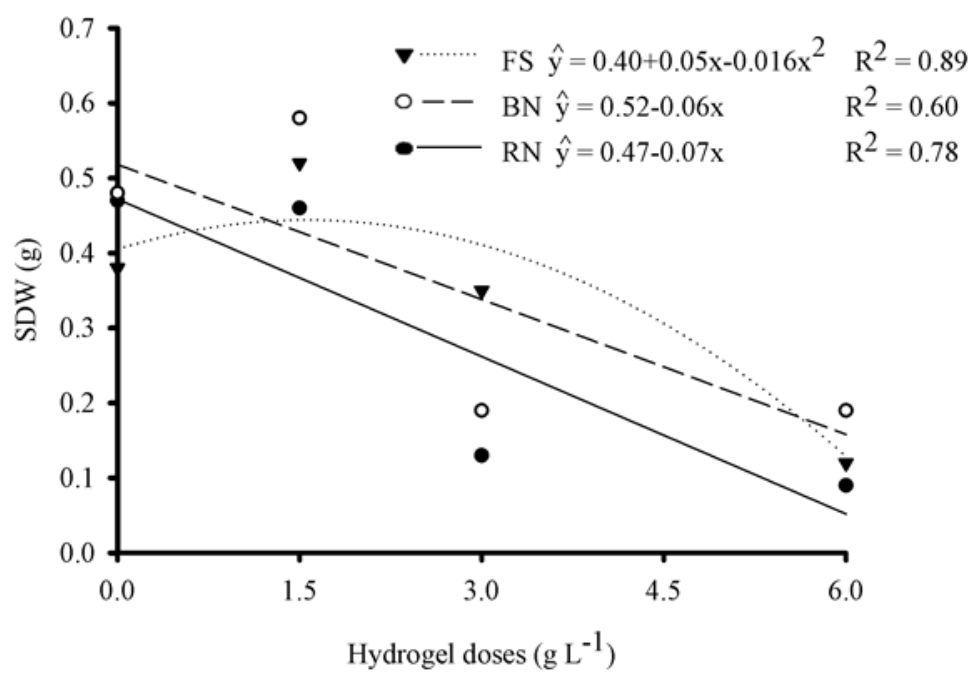

Figure 3. 'Crimson Sweet' watermelon shoot dry weights as a function of hydrogel doses and shading conditions (black net - BN; full sun - FS; and red net - RN).

Leaf area increased by $45.5 \%$ and $19.0 \%$ at $1.5 \mathrm{~g} \mathrm{~L}^{-1}$ compared to the control (Figure 4) under full sun and black net shading, respectively. However, hydrogel did not increase leaf area under red net shading. Furthermore, the change in the absorption spectrum caused by red net shading may have led to the leaf area increases in the absence of hydrogel. Fagundes et al. (2015) reported that the polymerhydrogel increased the leaf areas of yellow passion fruit seedlings; however, Dranski et al. (2013) found that it had no significant effect on jatropha seedlings.

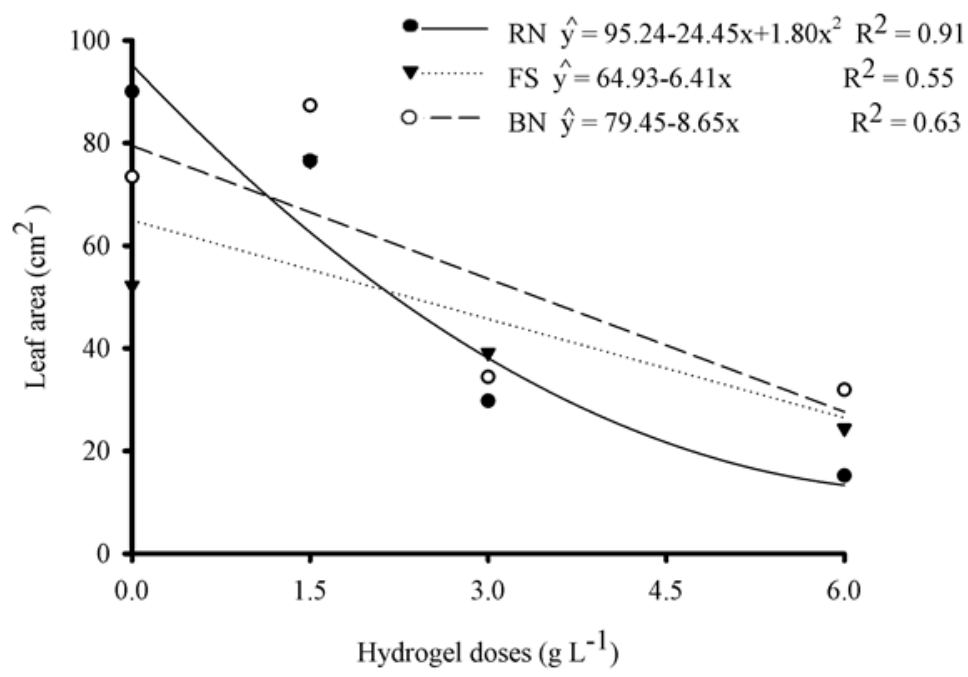

Figure 4. 'Crimson Sweet' watermelon leaf areas as a function of hydrogel doses and shading conditions (black net - BN; full sun - FS; and red net - RN). 
The plants under black net shading were longer than those grown under the red shading and full sun conditions (Table 2). There was only a significant difference in root dry weights between the plants grown under black net shading and those grown under full sun, but there was a significant difference in total dry weight between black net shading and red net shading (Table 2). These results indicated that the reduction in the incidence of radiation caused by black net shading avoided possible stress due to high temperatures. This may have improved metabolic activities and the incorporation of photoassimilates by plants, which would increase dry matter accumulation.

After evaluating the production of 'Crimson Sweet' watermelon seedlings in different environments, Oliveira et al. (2015a) reported that the dry weight shoot ratios were higher when the plants were shaded with a black net $\left(\right.$ Sombrite $\left.^{\circledR}\right)$. However, Henrique et al. (2011) found that the color of the nets did not affect the root dry weights of coffee seedlings.

Table 2. Mean values for the effects of the different shading conditions on root length (RL), root dry weight (RDW), and the total dry weight (TDW) of 'Crimson Sweet' watermelon plants and the significant differences (Tukey's test at the 5\% probability level) between the factors ${ }^{(1)}$.

\begin{tabular}{cccc}
\hline Shading conditions ${ }^{(2)}$ & RL (cm) & RDW (g) & TDW (g) \\
\hline FS & $20.35 \mathrm{~b}$ & $0.268 \mathrm{~b}$ & $0.610 \mathrm{ab}$ \\
BN & $27.27 \mathrm{a}$ & $0.359 \mathrm{a}$ & $0.720 \mathrm{a}$ \\
RN & $21.12 \mathrm{~b}$ & $0.303 \mathrm{ab}$ & $0.590 \mathrm{~b}$ \\
\hline CV (\%) & 25.33 & 30.33 & 23.48 \\
F-value & 0.00067 & 0.0135 & 0.0198 \\
\hline
\end{tabular}

${ }^{(1)}$ Means followed by the same letters in a column do not differ according to Tukey's test at the $5 \%$ probability level.

${ }^{(2)} \mathrm{RN}=$ red net; $\mathrm{BN}=$ black net; $\mathrm{FS}=$ full sun.

The results for the isolated effects of hydrogel dose on root dry weight, total dry weight, and root growth (Figure 5) showed that it had a negative linear effect on the three variables. The reduced plant root growth when hydrogel was added to the substrate suggested that there was a lack of aeration due to excess moisture in the substrate. This result agreed with Moreira et al. (2010). In addition, Montesano et al. (2015) reported that hydrogel led to excessive water storage in sandy soils.
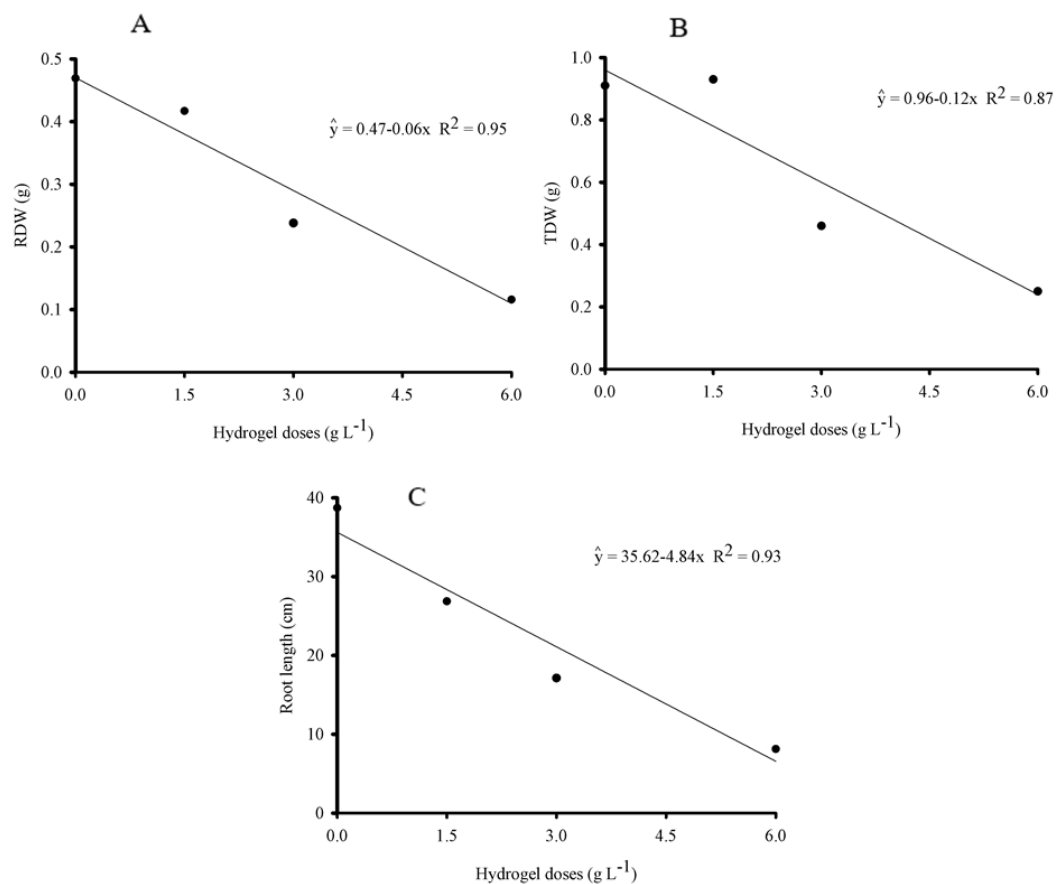

Figure 5. Regressions of the isolated effects of hydrogel dose on watermelon root dry weight (A), total dry weight (B), and root length $(\mathrm{C})$. 
Root growth plays an essential role in the absorption of water and nutrients by plants, and is directly related to dry matter accumulation. The root growth reductions at the highest hydrogel concentrations influenced nutrient absorption and assimilation capacity, and decreased root dry matter and total dry matter (Figure 5). These results differ from those reported by Demartelaere et al. (2009), who observed $25 \%$ gains in the root lengths of melon plants when using $27 \mathrm{~g}$ of the polymer per hole; and Santos et al. (2015), who reported increased root fresh weights for lettuce plants when up to $24 \mathrm{~g}$ of the polymer was added to each pot. This difference may be related to the type of product used and its effect on soil or substrate characteristics because the two previous studies were carried out in clay soils, whereas this study used a sandy substrate.

\section{CONCLUSIONS}

Hydrogel at $1.5 \mathrm{~g} \mathrm{~L}^{-1}$ leads to larger increases in 'Crimson Sweet' watermelon production, when they are grown under black net shading or full sun.

The most suitable shading condition for the cultivation of 'Crimson Sweet' watermelon was black net shading, because the plants accumulated more dry matter.

'Crimson Sweet' watermelon plants tended to etiolate when they were shaded with red nets.

\section{REFERENCES}

AHMED, E. M. Hydrogel: Preparation, characterization, and applications. Journal of Advanced Research, v. 6, n. 2, p. 105-121, 2015.

ARAÚJO, J. R. G. et al. Efeito do recipiente e ambiente de cultivo sobre o desenvolvimento de mudas de mamoeiro cv. Sunrise Solo. Revista Brasileira de Fruticultura, v. 28, n. 3, p. 526-529, 2006.

BERNARDI, M. R. et al. Crescimento de mudas de Corymbia citriodora em função do uso de hidrogel e adubação. Cerne, v. 18, n. 1, p. 67-74, 2012.

CÂMARA, G. R. et al. Avaliação do desenvolvimento do cafeeiro conilon robusta tropical mediante uso de polímeros hidroretentores e diferentes turnos de rega. Enciclopédia Biosfera, v. 7, n. 13, p. 135-146, 2011.

DEMARTELAERE, A. C. F. et al. Utilização de polímero hidroabsorvente no meloeiro (Cucumis melon L.) sob diferentes lâminas de irrigação. Revista Caatinga, v. 22, n. 3, p. 6-9, 2009.
DRANSKI, J. A. L. et al. Sobrevivência e crescimento do pinhão-manso em função do método de aplicação e formulações de hidrogel. Revista Brasileira de Engenharia Agrícola e Ambiental, v. 17, n. 5, p. 537-542, 2013.

FAGUNDES, M. C. P. et al. Polímero hidroabsorvente na redução de nutrientes lixiviados durante a produção de mudas de maracujazeiroamarelo. Revista Caatinga, v. 28, n. 1, p. 121-129, 2015.

GILBERT, C. et al. Effects of hydrogels on soil moisture and growth of cajanus cajan in semi-arid zone of Kongelai West Pokot County. Open Journal of Forestry, v. 4, n. 1, p. 34-37, 2014.

HENRIQUE, P. de C. et al. Aspectos físiológicos do desenvolvimento de mudas de café cultivadas sob telas de diferentes colorações. Pesquisa Agropecuária Brasileira, v. 46, n. 5, p. 458-465, 2011.

HOAGLAND, D. R.; ARNON, D. I. The water culture method for growing plants without soils. Berkeley: California: Agricultural Experiment Station, 1950. 39 p. (Circular, 347).

INSTITUTO BRASILEIRO DE GEOGRAFIA E ESTATÍSTICA - IBGE. Produção Agrícola Municipal. 2017. Disponível em: <http:// www.ibge.gov.br>. Acesso em: 18 out. 2018.

LOPES, M. B. S. et al. Cowpea bean production under water stress using hydrogels. Pesquisa Agropecuária Tropical, v. 47, n. 1, p. 87-92, 2017.

MONTESANO, F. F. et al. Biodegradable superabsorbent hydrogel increases water retention properties of growing media and plant growth. Agriculture and Agricultural Science Procedia, v. 4, s/n., p. 451-458, 2015.

MOREIRA, R. A. et al. Efeito de doses de polímero hidroabsorvente no enraizamento de estacas de amoreira. Revista Agrarian, v. 3, n. 8, p. 133-139, 2010 .

OLIVEIRA, A. M. D. et al. Produção de mudas de melancia em diferentes ambientes e de frutos a campo. Revista Ceres, v. 62, n. 1, p. 87-92, 2015 a.

OLIVEIRA, J. B. de et al. Rendimento e qualidade de frutos de melancia em diferentes épocas de plantio. Revista Caatinga, v. 28, n. 2, p. 19-25, 2015b.

OLIVEIRA, V. C. de et al. Respostas fisiológicas de plantas de orégano (Origanum vulgare L.) cultivadas sob malhas coloridas e fertilizantes orgânicos. 
Revista Colombiana de Ciencias Hortícolas, v. 11, n. 2, p. 400-407, 2017.

R CORE TEAM. R: A language and environment for statistical computing. Disponível em: $<$ https:// www.R-project.org/>. Acesso em: 18 out. 2018. 57

REGO, G. M.; POSSAMAI, E. Efeito do sombreamento sobre o teor de clorofila e crescimento inicial do jequitibá-rosa. Boletim de Pesquisa Florestal, s/v., n. 53, p. 179-194, 2006.

SANTOS, H. T. et al. Cultivo de alface em solos com hidrogel utilizando irrigação automatizada. Engenharia Agrícola, v. 35, n. 5, p. 852-862, 2015.

SHAHAK, Y. Photo-selective netting for improved performance of horticultural crops. A review of ornamental and vegetable studies carried out in Israel. Acta Horticulturae, s/v., n. 770, p. 161-168, 2008.

YANG, L. et al. Influence of super absorbent polymer on soil water retention, seed germination and plant survivals for rocky slopes eco-engineering. Ecological Engineering, v. 62, s/n., p. 27-32, 2014.

VICHIATO, M. et al. Crescimento e composição mineral do porta-enxerto tangerineira cleópatra cultivado em substrato acrescido de polímero hidrorretentor. Ciência e Agrotecnologia, v. 28, n. 4, p. 748-756, 2004. 